\title{
1975 TAPPI Coating Conference に出席して
}

\author{
東京大学農学部 門 屋卓 \\ 1975 TAPPI Coating Conference
}

\author{
Takashi Kadoya \\ Faculty of Agriculture, University of Tokyo.
}

\section{1.はじめに}

1975 年 TAPPI コーティング会議は 4 月 21 日 23 日の 3 日間にわたってシカゴ, コンラッドヒルトンホ テルで開催された。

筆者はたまたま米国・カナダ産業用紙調査団の一員 として渡航中で, 旅程をこのコーティング会議にくり 入れることが出来参加する機会が得られたので，その 概要をここに御紹介することにする。

3 日間の会議の内容は 15 件の研究発表, 四つの技 術委員会, 三つの連絡会議および㡺食会，2 コースの 見学会など極めて盛りたくさんなスケジュールである。 研究発表会場に集った参加者は大凡 400 人位と推定 され, 日本からの参加者も数名見受けられた。発表内 容は第 1 日目がコーティングバインダー関係，2 日目 はコート紙の分析, 評価, 3 日目がコーティングプロ セスの問題を主にとり扱った発表に区分され，これら はほとんど午前中に行なわれ，午後は上記の幾つかの 小委員会に時間をさいている。小委員会の内容はコー ティング添加剤，コーティングバインダー, コーティ ングピグメント，コーティングプロセス，レプログラ フィ，技術予測などの項目に分かれ，座長を中心に委 員と参加者がそれぞれ意見交換をする形式で同時に小 ルームで行なわれるので全部一人で参加することは出 来ない。

会議終了の翌日 24 日は工場見学会で, A グループ はシカゴの I.S. Berlin Printing Plant と Lithographic Institute, Bグループは Beloit Corpにそれ ぞれ貸切りバスで回ることになっていたが，筆者は次 のスケジュールがあり参加できなかった。

会議の前日は前夜祭があり, 簡単なカクテルパーテ ィで筆者らも含めた遠来の参加者をねぎらってくれた。 なお, 本会議の参加費は TAPPI 会員 $\$ 60$, 非会員 \$80, 工場見学 \$5 である。

\section{2. 研究発表の概要}

\section{第 1 日}

- Advantages of Co-Binder Coatings for Varied Printing Processes, …... G. ECKHART, St. Regis Paper Company, Battle Creek, Mich. (表 2，スライド 13)

カートン用オンマシンコートボードは加工面で多種 多様の取扱いを受ける。すなわち, 多方式の印刷ある いはカートン加工 (例えば接着性) などを考慮してバ インダーを選定しなければならない。

基材は末唒又は半晒のボードでェアナイフコート， ピグメントはクレイと二酸化チタンの混合を考え, 合 成エマルジョンラテックスとカゼイン, デンプン系の Co-Binderの組合わせで満足すべきコーティングカラ 一の条件を検討した。

グラビア印刷とオフセット印刷では紙に要求される 特性が異なり, 特にオフセットに対して従来の IGT やバンダクック試験機は問題があり, IGT に種々の ブランケットをつけて水をコート面に転写する方式に より良好な判定が可能となった。また, 新にインク保 持性, 水受理性, 毛羽立ちのテストとしてオフセット ピック試験, カートンの接着効果のためシール性のテ スターを開発し良好な結果が得られた。特に後者は接 着剤とアプリケータロール，試料間の動的な挙動をス トレンゲージで記録するもので, PVA-SB 系のコー ト面にはデキストリン系接着剤が有効なことが認めら れた。

- The Effects in Paper and Board Coatings of Carboxylated SBR Latex Particle Size with Protein Cobinder. ...... J. E. CARMICHAEL. General Tire and Rubber Co., Akron, Ohio. (表 10,図 7)

コーティングカラーバインダーとしてカルボキシル 


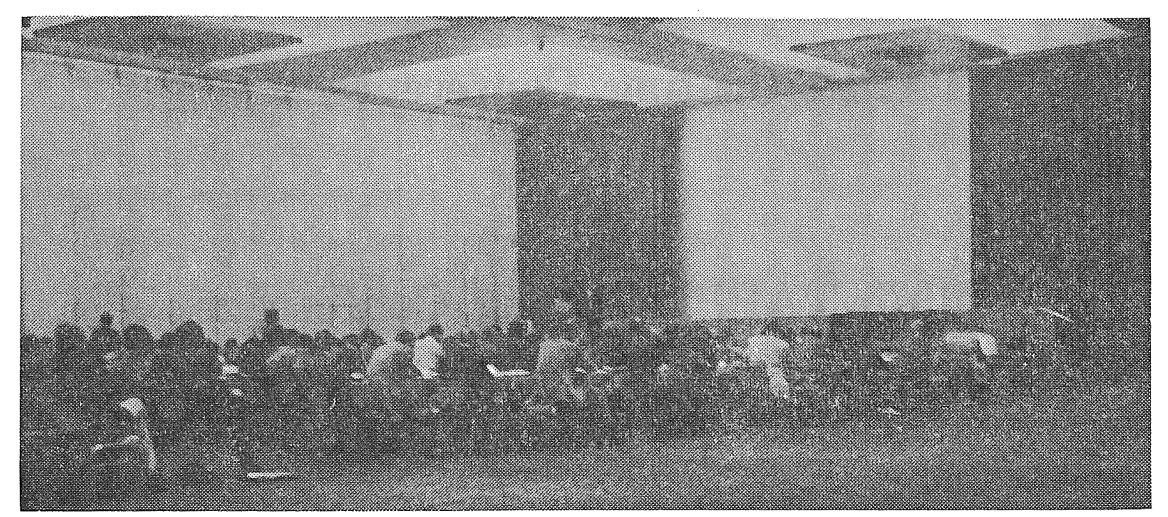

Conference の会場

SBR ラテックスが使われているが，その粒子径は 1,600 2,000 ̊̊ 内にある。これに Co-Binder として 大豆たんぱくを用いた場 合, SBR の粒子径の変化は コーティング特性に大きな影響を及ぼす。SBR ラテ ックスの粒子径を $1,100 \sim 1,200 \AA$ 内にある $\mathrm{A}, \mathrm{B}$ 試料, $1,800 \AA$ のC試料, $3,000 \AA$ のD試料について 特性の変化を求めた。ピグメントはカオリン 90 二酸 化チタン 10, ピロリンサン 0.1 で固型分 $40 \%$ で調成 し, 紙, 板紙に対し 2 種類のコート量で塗工しスーパ 一カレンダーがけをして武料を作った。

その結果を要約すると，

(1) SBR ラテックスの 粒子径は SBR-たんぱくの Co-Binder系についてコーティングカラーのレオ ロジーとシートの表面強度にかなり影響を及ぼす。

(2) カラーの粘度は低いずり速度ではラ テックスの粒径が増加すると減少する が，高いずり速度では顕著ではない。

(3) 1,800 ̊̊ のラテックスではウェット ピック，ドライピック，デキストリン 接着性などの強度特性は最低值をとり, $1,100 \sim 1,200 \AA$ と $3,000 \AA$ に対して は上記特性值は同じであった。

このような特性值の相違は $\mathrm{KN}$ インク吸 収やウェットラブ抵抗でも顕著に現われる が，これはポリマー成分の影響が大きく影 響しているかも知れない。

- Development of Total Synthetic Binder for Rotogravure Paper,....... D. I. LEE, H. W. LOUMAN and M. H. MOSS, Dow Chemical Co., Midland, Mich. (写真 4, 表 2, 図 10) 米国のグラビヤ印刷は今後も更に進展す
ると思われるが，そのため合成バインダーの研究と開 発がさらに必要であり,この評価方法を種々の角度か ら検討した。

Black Paper Hiding Test は無反射の黒色紙にカラ 一を㓌工しブライトネスを求める方法で, この值の高 いものは良好なグラビヤ印刷適性が得られる。Heliotest はフランスで開発され，IGT テスタに 80 40 $\mu$ のグラビヤメッシュをとりつけテストする方法で, 約 50 倍に拡大観察し， 20 個の網点がくずれた 試料の長 さで表示する。長さが長いほどグラビヤ適性がよい。

また, Huber Test は試料面を $50 \mathrm{~g} / \mathrm{m}^{2}$ の軽い荷重 でこすり, 規定の目方の紙粉が出るまでの回数で表示 する。Nopco Test は規定の金属板のエッジで試料面 を 5 回研磨し，このダストを集め計量する。

表 1 Rotogravure Printability

\begin{tabular}{|l|r|r|r|r|}
\hline & $\begin{array}{r}\text { "BAD" } \begin{array}{r}\text { Binder } \\
\text { System }\end{array} \\
\text { Clay }\end{array}$ & $\begin{array}{r}\text { "GOOD" } \\
\text { Binder } \\
\text { System }\end{array}$ & $\begin{array}{r}\text { EXP. } \\
\text { Binder } \\
\text { System }\end{array}$ \\
Latex & 100 & \multicolumn{2}{|c|}{100} & 100 \\
\% Solids & 7 & \multicolumn{2}{|c|}{7} & 7 \\
Hi-Shear Viscosity & 43 & 60 & 60 & 60 \\
Coat Weight & 66 & 57 & 60 \\
$75^{\circ}$ Gloss-6 Nips & 48 & 55 & 56 & 56 \\
Heliotest, 6 Nips & & & & \\
$\quad$ 10kg, mm/20 Missing & 16 & 39 & 48 & 46 \\
$\quad \begin{array}{l}\text { Dots } \\
\text { Visual Appearance- }\end{array}$ & Exc. & Fair & Exc. & Exc. \\
\hline
\end{tabular}




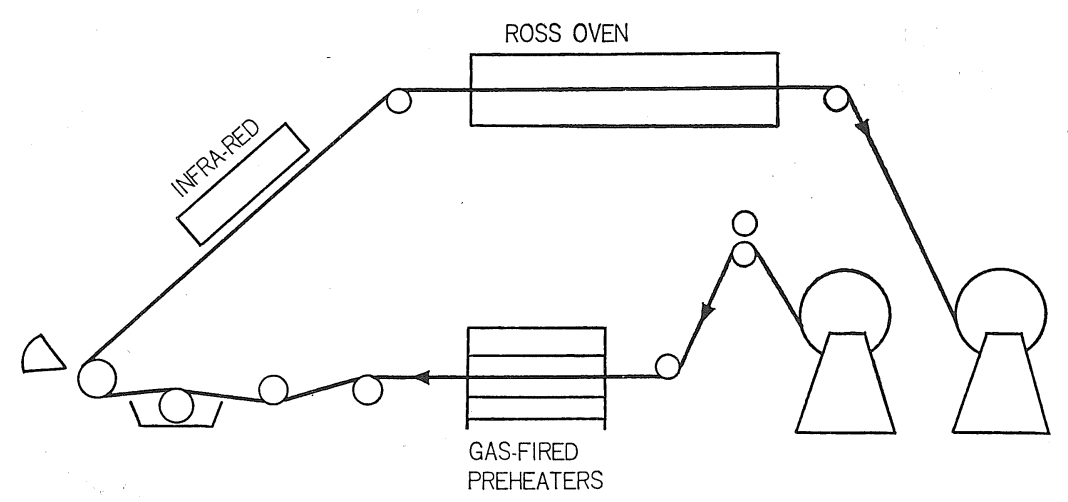

図 1 Pilat Coater Arrangement

このような試験結果から $\mathrm{S} / \mathrm{B}$ ラテックスの $\mathrm{S}$ と $\mathrm{B} の$ 比率が $50: 50$ が最も良い結果が得られた。

更にラテックスとクレイの相互作用については液体 クロマトグラフを用いることでかなり良く特徴がつか まえられ, Hercules 粘度計によって高速コーティン グの作業性を知ることができる。これらの測定法によ ってカラーのグラビヤ適性を求めた一例を表 1 に示す。

- Optimization of the Properties of Coated

Board ...... P. J. ASCHAN and J. PAAKKO,

The Finish Pulp and Paper Research Institute,

Helsinki, Finland (表 5, 図 5 )

18 in 幅のパイロットコーターを用い $240 \mathrm{~g} / \mathrm{m}^{2}$ の フォルデングボックスボードに $16 \sim 22 \mathrm{~g} / \mathrm{m}^{2}$ のコーテ ィングを行ない,コート量の変動要因の統計的解析を 行なった。カラーはチャイナクレー, SB ラテックス, $\mathrm{CMC}$ で調成し, 乾燥は $160^{\circ} \mathrm{C}, 328 \mathrm{ft} / \mathrm{min}$ で行なっ た。その結果を要約すると，

(1) コート量はエアナイフ圧と固型分濃度の変動に よって変化する。

（2） KN インク吸収は固型分濃度の増加, エアナイ フ圧の減少，バインダー濃度，乾燥速度の増加に 対して減少する。

(3) Bentsenあらさはェアナイフ圧の低下で増す。

(4) ブライトネスはェアナイフ圧の増加, 固型分, バインダー濃度の減少に対して低下する。

(5) グロス（ブラッシュカレンダーなし）は固型分 濃度の増加とエアナイフ圧の減少に対し増加する。

（6） IGT 表面強度はバインダー濃度の変動によっ て変化する。

- Coat Weight Variation For Evaluating Binder Migration of Air Knife Coating on Unblea- ched Kraft Board …... L. M. WISE Alabama Kraft Co., Phenix City, Ala (図 12)

オフセット印刷の問題点の一つであるバインダーマ イグレーションの検討のために図 1 のようなパイロッ トコーターを用いて, コーティング速度, 乾燥条件, シート温度，原紙の影響などを調べ，また種々のラテ ックスおよびデンプンに対し，その比率，添加剤の影 響などについて考察した。マイグレーションの尺度と して KNインキ試験を採用し，コーティング速度 300 〜00 fpm, コート量 $1.5 \sim 3.5 \mathrm{lb} / \mathrm{MSF}$ でコート量の 調整はエアナイフ圧で行なった。その結果は下記の通 りである。

(1) エアナイフによるコート量はバインダーマイグ レーションの最も重要な因子である。

(2) コーティング速度が増加するとバインダーマイ グレーションが増加する。

(3) エアナイフコーティングの前でシートをプレヒ 一トするとマイグレーションが減少する。

(4) 赤外線乾燥を行ならことでマイグレーションを 減少した。

(5) Sodium alginate の利用はマイグレーションを 減少させる。

(6) デンプンはラテックスよりマイグレーションし やすく， ラテックス/デンプンの比が増すとマイ グレーションが増加する。

（7）デンプンの選択により粘度が上り操業の限界值 となる。

図 2, 図 3 にKNインク試験に対するコーティング 速度およびプレヒーティングの関係の一例を示した。

- Case Histories in Solving Coating Problems with the Electron Microprobe...... B. W. CE- 


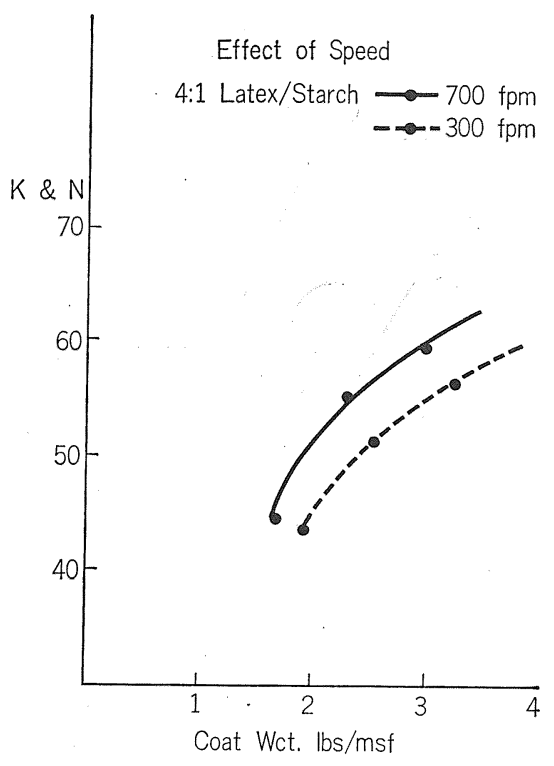

図 2 Effect of Speed

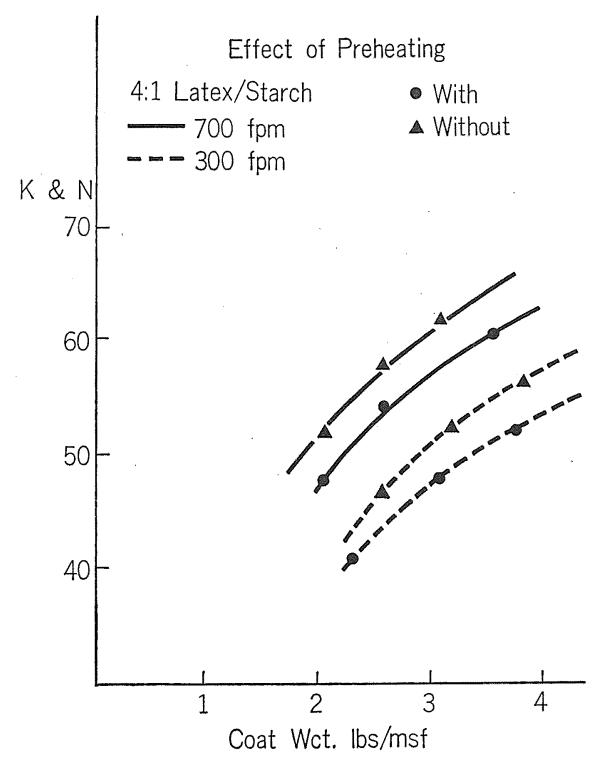

図 3 Effect of Preheating

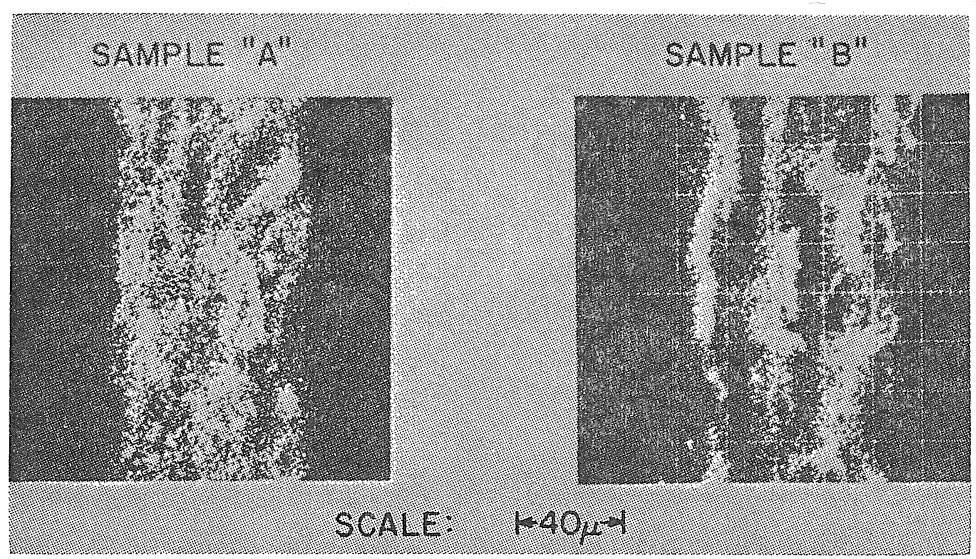

図 4 Titanium Dioxide Distribution in Paper

TNAR and I. H. HEITUR, E. I. du Pont, Wil mington, De (図 11, カラースライド11)

この発表は電子線マイクロアナライザーを用いてコ 一ト紙の表面および横断面の観察を行ない，印刷時の 各種トラブルの発生原因とを結びつけたものである。 この装置は現在世界で 700 台以上が用いられ，米国で も 400 台が広い研究分野に用いられている。紙の横断 面の観察にはビームスポット $0.5 \mu$ が適当で図4は二 種類の市販の内填紙に対して二酸化チタンの紙層内の 分布状態を調べたものである。試料Aは填料が均一に 分散しており，効果的に不透明度を向上しているが， 試料 Bは填料の分散が悪く不透明度が効果的に上って いないことを示している。この装置はまた半定量的な
測定も可能で, $0.5 \times 270 \mu$ の範囲を走査し反射二次電 子線の強度を求めることで分布曲線を得ることができ る。図 5 は平均 $4 \%$ の二酸化チタンを内填した紙につ いて半定量的測定を行なったもので, 試料 $\mathrm{A} ， \mathrm{~B} の$ 相 違が明りょらに示されている。紙の表面特性の観察で はコート層の表面に埋没している顔料の同定が可能で, 極めて有効な情報を提供できる。反射二次電子線の信 号をフィルター回路にかけることによって各種顔料の 相違をカラーでディスプレイすることができる。この 説明にはスライドを用いてピッキングトラブルを起こ したさート板紙の表面層に埋没している末分散の二酸 化チタンを検出し, その中のチタン成分, シリカ成分, アルミニウム成分などを緑, 赤, 黄に色分けした幾つ 

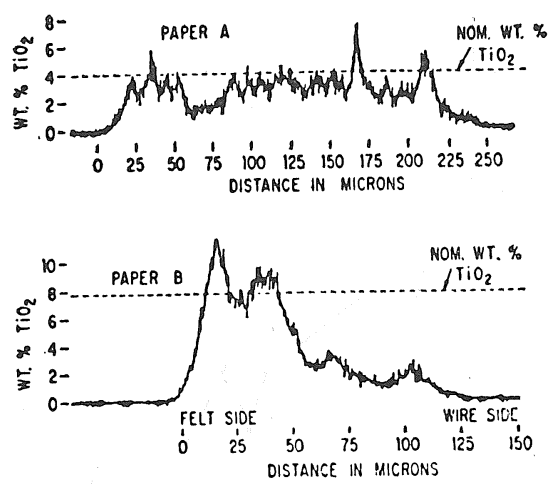

図 5 Cross Sectional $\mathrm{TiO}_{2}$ Profile

かの例について発表がなされた。更にコーティングカ ラーの紙への浸透状態を観察するために，この装置は 有効で浸透の異なる 2 種類の紙のカラーの横断面図と この中に二酸化チタンがどのように浸透しているかが 示された。

- The Effect of Mixed Binder Systems on the Film Volume and Pore Size Distribution of Isolated Clay Coatings ...... C. L. GAREY, R. M. LEEKLEY, and J. D. HULTMAN, The Institute of Paper Chemistry, Appleton, Wis. (表 2, 図 5)

これについては Tappi Vol. 58, No. 5, p. 79 に発 表されており，ここでは簡単に紹介する。

PVAc（ポリビニルアセテート）を含んだコート紙 は大きいインク受理性を示す原因を追究するために， デンプンや大豆タンパクと S/B ラテックス, PVAc ラ テックスの混合したクレイコーティングフィルムの孔 径分布を求めた報告である。コーティングフィルムは, スズはくの上にカラーをアプリケータで塗り, 乾燥後 スズを水銀でとかしてフィルムを分離した。

孔径分布は水銀圧入式のポロシティメータを使って 求めた。PVAc ラテックスを含むコーティングフィル ムは $\mathrm{S} / \mathrm{B}$ ラテックスより大きい孔径容積と孔径を持っ ている。S/B ラテックスのコーティングのインク受理 性が低いことは軟い微粒子がコーティングでの自然の 粒子間の空陌に順応することによるためで, そのため に全孔径容積と孔径が減少する。一方, PVAc の粒子 は硬いので, コーティングに際してのコート層の形成 に制限を示し孔径容積と孔径が増加している。

- An Improvement in the Determination of $R_{\infty}$ and Scattering Coefficients for Paper, Pigment and Coatings. Part 1. ..... R. E. STARR and

R. H. YOUNG. Freeport Kaolin Co. Gordon,

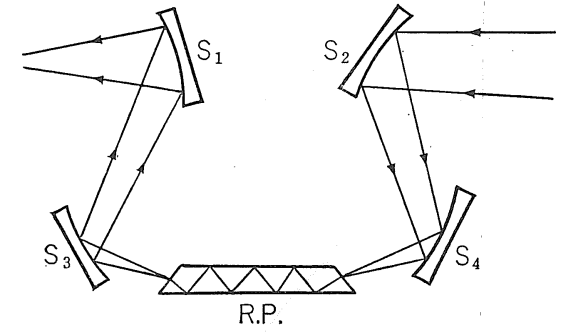

$S_{1}, S_{2}, S_{3}$, and $S_{4}$ : Concave mirrors-R. P. : Reflector plate

図 6

Georgia

この報告も前報と同じく Tappi，p. 74 に掲載され ている。

紙やコート紙などの反射率や不透明度は，いわゆる Kublka-Munk の式の $S$ と $K$ の価に依存しており， 一度これが決まると，コート原紙，コート紙，板紙な どの紙の各種の坪量に対して Kubelka-Munk の式か ら光学的性質を予測することが可能である。しかし， 低坪量の紙や不透明度の低い紙では計算值と実測值と ではなかなか合わない。そこで定数 $S$ の係数を正確に 決め䛊差を除去するグラフィカルな方法が提案された。 これによって $R_{g}$ といら変数が求められ，KublkaMunkの式の変形として用いられ低い不透明度のオ一 バレイ紙などの反射率にこれを適応させた。

- An Application of Infrared Spectroscopy to the Studies of Binder Migration in Paper Coatings …..E. E. HUANG and J. E. KLINE Dept. of Paper Sci. and Eng. West Michigan

Univ. Kalamazoo, Michigan

過去 10 年ほどの バインダーマイグレーションの研 究としては，1. Liquid Spreading, 2. Optical Measuremcnt, 3. Conductance Method, 4. Gravimetric Method, 5. Slant Sectioning, 6. Radioactive tracing, 7. Sound Velocity Method な゙があげられ るが，これらは複雑な手法が必要で結果も半定量的な ものが多い。本報は赤外線分光計に多重反射装置を取 付けマイグレーションの検討を行なっており測定の原 理を図 6 に示した。

カラーはカゼインークレイ系とアクリルラテックスー クレイ系の 2 種類が調成され, ウェストミシガン大学 のエアナイフコーターで種々の速度でコーティングさ れた。カラー濃度, コート量, 原紙は一定でコーティ ング速度は 200〜500 fpm で行ない，また乾燥速度を 変えた試料も作製した。これを Sanford Model LG のサーフェスグラインダーにかけて表面を削り赤外線 


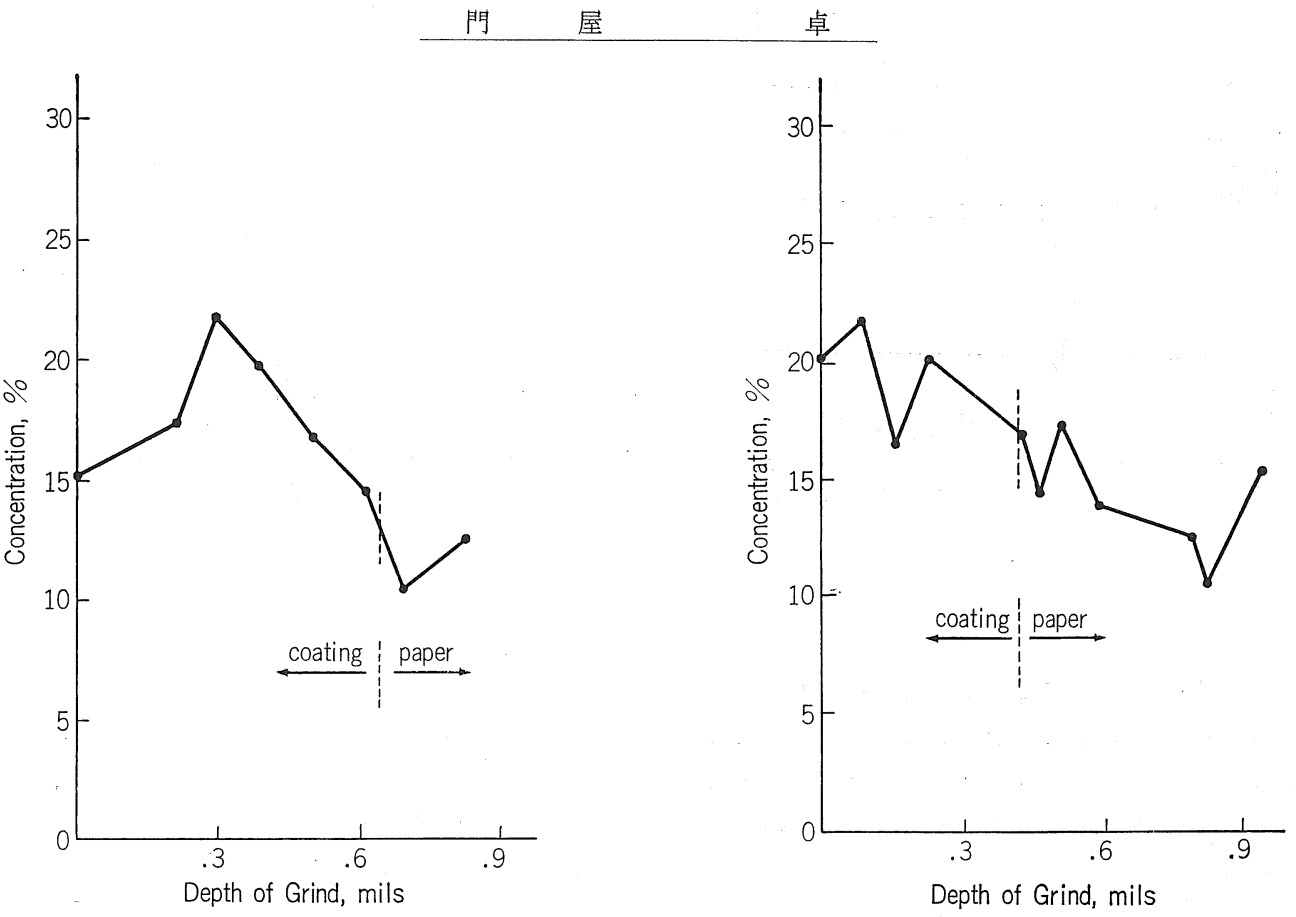

図 7 Binder migration curve for caseinclay coating, coated at $250 \mathrm{fmp}$.

図 8 Binder migration curve for caseinclay coating, coated at $450 \mathrm{fmp}$.

分光計にかけた。このサーフェスグラインダは表面を 0.0001 in の厚みの研削ができるよらに調節可能で， 研削した紙はプレスされた後分光計にかけられる。

分光計は Perkin-Elmer 700 ダブルビーム赤外線分 光計で，これにWilks Scientific Corp. の Model-50 のアタッチメントを取付けた。カゼインークレイ系, アクリルークレイ系のコーティング速度に対するマイ グレーションの変化の相違の代表的な結果を 図 7,8 に示した。

この実験の結論として,

(1) サーフェスグラインダを用いて多重反射式赤外 線分光計からコート紙の表面状態を分析すること によってバインダーマイグレーションの定量的な 測定が可能である。

(2) バインダーマイグレーションにはコーティング 後の乾燥速度とコート原紙の影響が大きい。コー ティング速度が遅いとバインダーマイグレーショ ンが起きやすい。

（3）カラーの固型分が増すとわずかにバインダーマ イグレーションが起こる。

- Coat Weight by X-Ray Florescence …… F. P. ARENDT and W. D. OLESON, Consolidated Paper, Wisconsin Rapids, Wis.

塗工工程でのコーティング量の管理というものは極
めて重要なテーマであるが，これをオンライン中で直 接求めることはかなり困難であった。本報は試料にX 線を照射し，この䖢光反射強度を測定することによっ てコート量を測定する方法について述べている。この 実用化についての問題点は放射線に対する安全性で, X線の外部散乱を最小にするために開口部以外は密閉 し開口部の周辺は鉄板で遮蔽した。X線源はタングス テン管球で $50 \mathrm{kV}, 30 \mathrm{ma}$ ，検出はシンチレーション カウンターで, この量をディジタルにプリントアウト する。この原理図を図 9, 10 に示した。この実験のも ら一つの問題点はトレーサーの選定である。種々の材 料について検討した結果，酸化亜鉛が最適であるとい ら結論を得，カラーに0.5〜1\% 添加することにした。 コート量とX線蛍光反射量との関係を図 11 に示す。 実用試験は 20 in 幅のパイロットコーターで行なわれ， コータブレードの刃の摩耗状態によりコート量が大き く変化することを確認した。

- Developments in Filtration of Aqueous Clay Coatings Since 1960 ….. TOMAS L. REECE \& DANNY K. KAISER, Ronningen-Petter Division/Dover Corp. Portage, Michigan (図 6) 1960 年以来, コーティング用として使われたクレイ の沪過装置の概要を述へ，更に新しい装置の紹介を行 なっている。クレイの沪過装置として以下の五つの特 


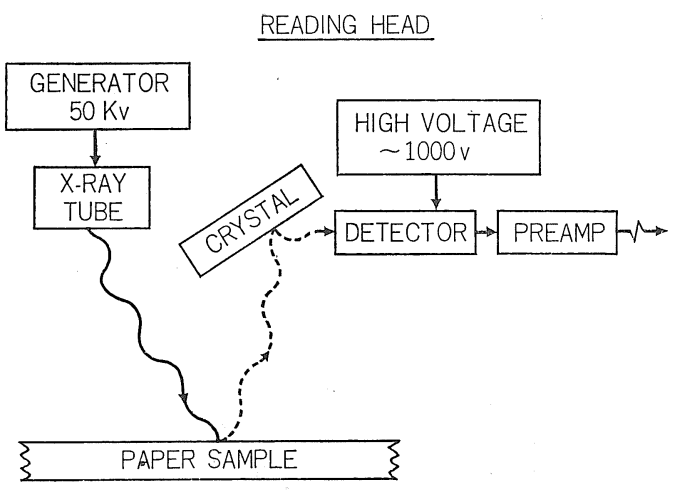

図 9 Reading head

\section{CONTROL \&:READOUT UNIT}

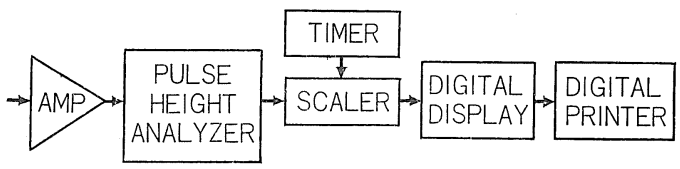

図 10 Control \& Readout unit

徵が述べられた。

1. Vibrating deck type

2. Scraper blade type

3. Pressure filter type

4. Pressure rotating disk type

5. Positive vibrating filter

図 12 は Positive vibrating filter を示す。

- Correlation Between Drying Conditions and Quality of Coated Paper......WALFGANG E.

GÄRBER, BASF Aktiengesellschaft 6700

Ludwigschafen/Germany, (図 18)

コート紙の品質を左右する因子はいろいろあるが, ここでは乾燥システムに着目して紙の個有蒸発速度 $Q_{P}$ と乾燥面の個有乾燥速度 $Q_{H}$ がコート紙の品質に 対して関数関係があることを述べている。実験は 80 $\mathrm{cm}$ 幅, $80 \sim 1,000 \mathrm{~m} / \mathrm{min}$ のパイロットブレートコー ターで行なわれ，乾燥部は図 13 に示されるよらにガ ス赤外線乾燥器 5 基, ホットエア乾燥器 2 基, 高速エ アキャップ 1 基を配置している。品質の評価の尺度に IGT インク乾燥試験をとりあげ，例えば図 14 の如き 結果を得た。その他カラー固型分, 塗工方式 (シング ルとダブル) などの結果から次式が得られた。

品質 $(\mathrm{S})=\left(Q_{P}\right)^{3}+Q_{H}$

- Coating Reclaim at Consolidated Paper, Inc.

Wisconsin Rapids Division.......LEO J. WELL-

ING and WILLIAM C. VREELAND, Consolidated Paper, Inc. Wisconsin Rapids, Wis

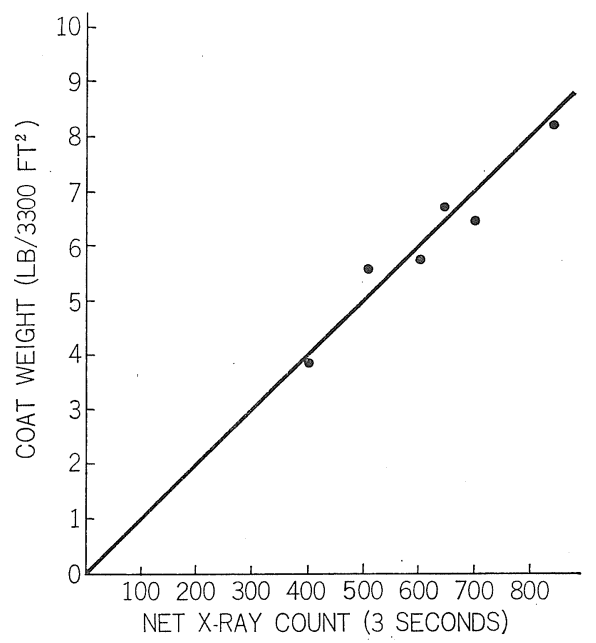

図 11 Coat Wts Using Oven Dry Wts vs. X-RAY counts

(図 4)

同工場にはサイズプレス付の 4 台の抄紙機と 2 台のオフマシ ンコータがあり，省資源と排水 対策としてコーターラインに $300 \mathrm{gal}$ の予備タンク，ブロー クビータの新設, ブレードのカ ラーをフィラーとして利用する 設備の新設を行ない，銘柄変更 時の洗浄によるカラーの回収と 再利用を計画した。

その結果は 1 日 3〜4tの原料 節減となり，クラリファイヤー の負荷が減少し，BODの低下， スラッジ運搬費の節約につなが った。一方，このシステムのコ ストは $\$ 65,000$ と多少のメンテ ナンスコストがかかったが， 1974 年で $\$ 150,000 \sim \$ 200,000$ の節減がもたらされた。

- Burnout, A Coat Weight Determination Test $\mathrm{Re}$ Examined ….. RONALD

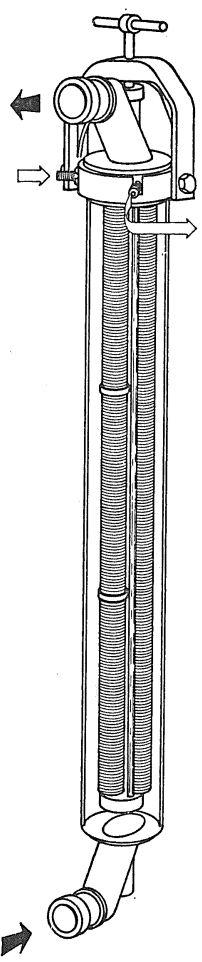

図 12
L. DOBSON, Continental Can Company, Inc.

Augusta, Georgia (表 8, 図 2)

同社で 1940 年来行なわれている現場でのコート量 の測定法について述べられた。これは Burnout テス トと称し，採取した試料を $25 \mathrm{~g}$ の塩化アンモンに 500 $\mathrm{m} l$ のプロピルアルコールと $500 \mathrm{~m} l$ 蒸溜水で希哷した 


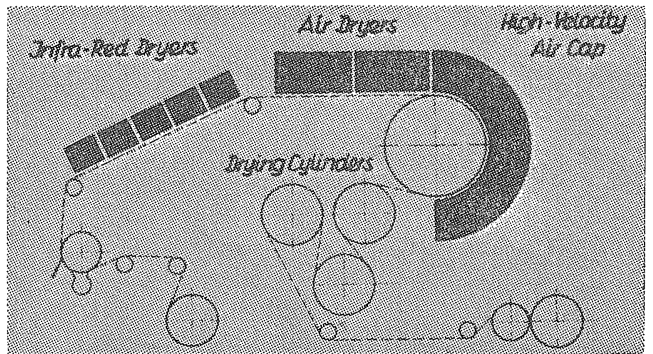

図 13 Design of Experimental Coating Machine

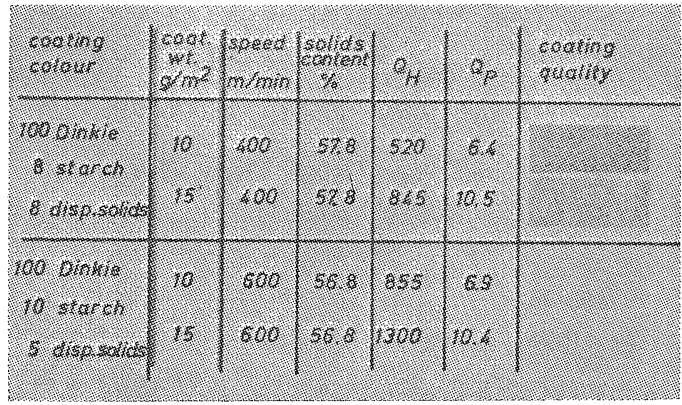

図 14 Coat Weight and Coating Quality

液で No. 20 のマイヤバーを用いて表面に塗布する。 これを $400^{\circ} \mathrm{F}$ の回流式の乾燥機中で規定時間乾燥後, コート面の明度Lをハンターで測定する。試薬の塗布 量, 乾燥時間, 温度などある程度の精度があればコー 卜量と L 值の間には図 15 のように対応值が得られ, この曲線より末知のコート紙の塗工量が一応の精度で 求められる。現在, コート板紙のコート量の迅速決定 法として用いられている。

- The Twinblade Coating Process......HANS I.

WALLSTÉN, Inventing SA Lausanne,

Switzerland (図 13,シネ)

2 枚のブレードで紙の両面を同時に塗工する方法に ついて, 過去の開発の問題点についてまず説明があっ た。これらの問題の解決の一つとして BILLBLADE PROCESS が開発され, 現在世界で 35 台が使われて いる。更にツインブレードコーティング方式が検討さ れ，図16，17 にその原理図を示した。この装置の特 徵は回転部分がないことで, 固定した二つのアプリケ 一タからカラーが噴出し 2 枚のブレードで塗工が行な われる。この間, 紙はアプリケータとブレードで保持 安定しているのでフラッタリングが少ない。図 17 は 紙通しのときのコーティングヘッドの状態を示し，こ の辺の操作についてはカラーのシネフィルムにより詳 細な解説があった。

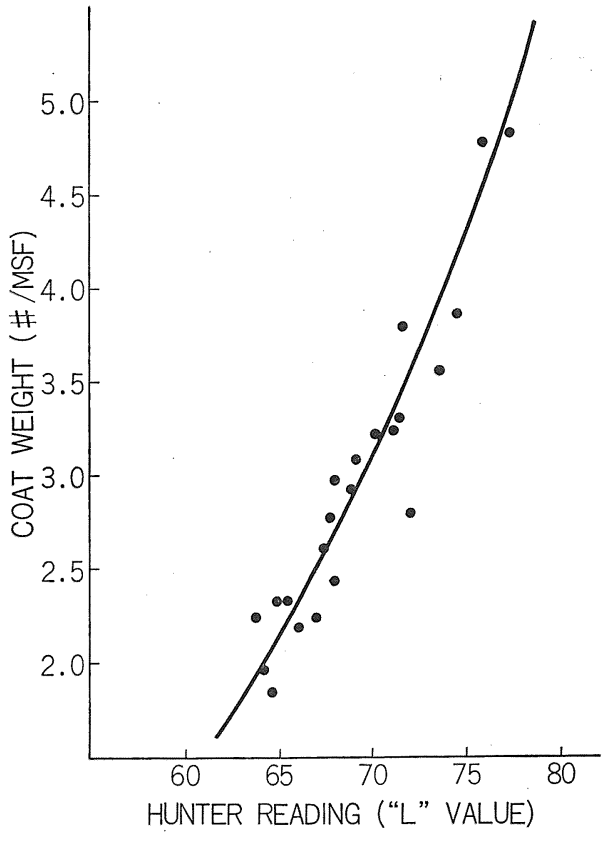

図 15 Coating II.

Coat Weight vs Hunter "L" Value

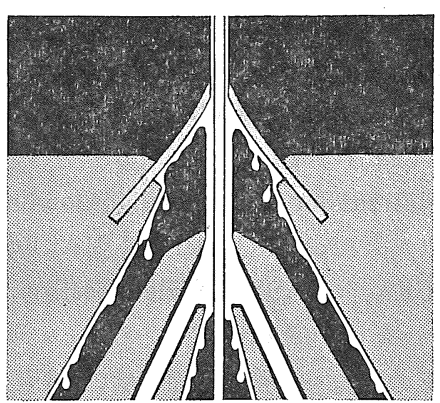

図 16

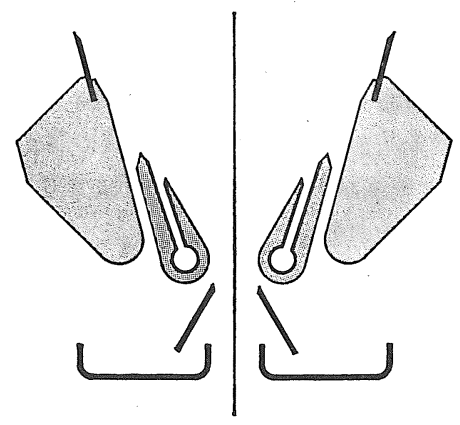

図 17 
ブレードの位置決めは装置上の重要なポイントであ るが,コート量の変動が少ないことは本機の特徵でも あり, また片面ずつ別々のカラーが塗工出来, カール 防止剤で裹面を処理することにより，かなり平坥な紙 が得られると力説している。

現在，パイロットテストが完了し，スウェーデンの $110 \mathrm{in,} 600 \mathrm{fpm}$ の抄紙機のサイズプレスパートを撤 去し本装置が設置されている。

カラー濃度は $50 \sim 54 \%$ で 10 $13 \mathrm{~g} / \mathrm{m}^{2}$ の塗工がで きるが，パイロットの段階ではカラー濃度 $60 \%, 16$ $\mathrm{g} / \mathrm{m}^{2}$ が実施されている。

\section{3. まとめ}

以上 3 日間にわたる Tappi Coating Conference の
概要を紹介したが, 紙数の関係で十分な内容までご報 告できなかった点御了解願いたい。

会議の出席者としての感想では, 発表の内容が紙の コーティングのみならずむしろ板紙のコーティングが 多分に含まれていることで，これは米国の Packaging に対しコーテッドボードの果す役割が大きいことを意 味するものであろう。

わが国の文化用紙と産業用紙の比率は最近次第に米 国型の比率構造となりつつあり, Packaging に関連し たコーティング分野も次第に重視されてくるであろら。 そういった意味で，本報が今後行なわれる Coating Conference に参加される方々の何等かの参考になれ ば幸である。

\section{TAPPI Annual Meeting}

主 催: Technical Association of the Palp \& Paper Industry

場 所: New York Hilton

期 間 : 1976 年 3 月 15 日一 17 日

参加費 : TAPPI 会員 : 45 ドル

" 非会員 : 70 ドル

（注）締切り日（2 月 13 日）以降の申し込みは会員は 20 ドル，非会員は 15 ドル増し。 照会先 : Mr. W. H. Gross.

TAPPI.

One Dunwoody Park, Atlanta, Ga., 30341 U.S. A. 